\section{THE ECONOMIC POSITION OF GREAT BRITAIN}

$\mathrm{T}$ HE White Paper "Economic Survey for 1947" (H.M.S.O. Cmd. 7046. 1947. 6d. net), which has followed the earlier "Statement on the Economic Considerations Affecting Relations between Em. ployers and Workers" and the "Statement Relating to Defence" (Cmd. 7042. H.M.S.O., 1947. 2d. net), gives a frank and sombre account of Great Britain's economic position. Less exhortative than the earlier one, its chief weakness is the absence of any real indication of the plan of action and the concerted measures by which the Government proposes to meet the danger. None the less, it is a most welcome instrument for educating the people of Great Britain in the true facts of the situation and their individual and collective implications, and every weapon of publicity should be used to bring those facts and implications home to every voter. As the Prime Minister rightly says in the foreword, it is the duty of any democratic Government to take the people frankly into its confidence, however difficult the position of the country may be; and again, "The Government alone cannot achieve success. Everything will depend upon the willing co-operation and determined efforts of all sections of the population. It is essential that all should understand that the maintenance and the raising of the standard of life of the people depends upon the extent to which every individual plays his or her part in contributing to the sum of goods and services available to the nation."

No exception can be taken to the presentation of the facts in the White Paper itself. They are displayed clearly and Iucidly and cogently marshalled in support of the argument. There is first a section outlining the nature of economic planning and the considerations upon which democratic planning must be based. Thus early there is the frank warning that if more is required to satisfy any one of the five main national needs-defence, payment for imports, capital equipment and maintenance, personal consumption, and public services-which the twenty million workers in Great Britain, producing goods and services to the value of more than $£ 8,500$ millions a year have to satisfy, it can only be at the expense of the others, unless the total amount of work done is increased. If the total resources are reduced by unemployment or by a fall in the output per manyear, less of these requirements can be met.

The White Paper then proceeds to outline the conditions to which economic planning must conform in order to preserve the maximum possible freedom of choice to the individual citizen. Not only must there be regard to our special economic conditions; it is of the first importance that planning in Britain should be as flexible as possible. In avoiding the waste of unemployment, we should not destroy the essential flexibility of our economic life. The Government is seeking to develop a system which comprises an organisation able to gather sufficient knowledge and reliable information to assess the national resources and to formulate the national needs, a set of economic 'budgets' which relates these needs to the country's resources and enables the Government to determine the best use for the resources in the national interest, and methods the combined effect of which enables the Government to influence the use of resources in the desired direction, without interfering with democratic freedoms.

"Resources can be increased by increasing the labour force, or by a bigger output per man-year or by a combination of the two. A reduction in the labour force or a reduction in the output per man. year-by lower efficiency or by shorter hours or increased holidays unaccompanied by a compensating increase in hourly output-reduces the total resources and means that even less of the requirements can be met than before. Planning the allocation of resources between the various national plans is at present a task of deciding which out of a number of claimants must go short-in other word's', which are the more important national priorities." While, however, the Government must lay down the economic tasks for the nation and say which things are the most important and what the objectives of policy should be, giving as much information as possible to guide the nation's economic activity and using its powers of economic control to influence the course of development in the right direction, the execution of the plan is a matter for co-operation between Government, industry and the people.

Reviewing next the period July 1945-December 1946, the Statement points out that the defence sector (armed forces and munitions) has been reduced from about 42 per cent of the nation's man-power to less than 10 per cent, and in this re-allocation unemployment in Great Britain never exceeded 2.5 per cent of the insured population, nor, in general, outside the Development Areas, $1 \cdot 5$ per cent. Exports have expanded to 110-115 per cent of the 1938 volume, and in 1946 industrial equipment and maintenance reached a normal pre-war year's work. Homes have been provided, by new building and repair, for nearly 300,000 families, and the way has been cleared for as rapid an expansion in housebuilding as the material supplies will permit. There has been little change on balance in food consumption; but a considerable expansion in supplies of manufactured goods to the home civilian markets to levels ranging from two-thirds to more than 100 per cent of pre-war years. Although far more plentiful supplies must be available than before the War to remove shortage in the shops, for a large section of the people the present food and clothing rations are more than they could normally afford even in good pre-war years.

In passing to the situation in 1947 , the White Paper, like its predecessor, drives home the central fact that we have not enough resources to do all that we want to do, and barely enough to do all we must do. Whether we reckon in man-power, coal, electricity, steel or national production as a whole, to get all we want, production would have to be increased by at least twenty-five per cent. The essential priorities are picked out with brutal frankness : first importance must be attached to payment for imports and to basic industries and services, particularly coal and power. These requirements are then explained and related to the general plan, and the broad conclusion reached that the export target of 140 per cent of 1938 volume by the end of the year is of prime importance. Exports to the western hemisphere (and some European countries, with which we have deficits, namely, Sweden, Switzerland, Portugal) are of particular importance, for they earn dollars or the equivalent and pay for our essential imports from these countries. Close import control must be maintained, particularly of products which 
come predominantly from the western hemisphere. Home production must be increased along lines which contribute to these policies, agriculture and shipping being of major importance in this connexion. Special reliance, it is considered, should be placed upon a substantial growth of engineering, vehicle, chemical and miscellaneous exports. The labour force in manufacturing industry already employed on orders for export is about 50 per cent above the pre-war level, and is capable of further expansion provided that fuel and power supplies are adequate. These export targets cannot be achieved at all readily and sometimes not at all without reducing production available for the home market.

The basic fact of the position of Great Britain over the next few years is that we must devote at least 25 per cent of our manufacturing capacity to the production of exports ; and we need to export more than this if we are to get the imports necessary to raise our standards of living. Equally important is the restoration of the full efficiency and productive power of our basic industries. Here it is urged that the 1947 industrial problem is fundamentally one of coal. We cannot afford to set a lower production target for the year than 200 million tons of coal, and this is barely onough for current use and for stock.

To achieve it the Government proposes to increase the labour force by making the industry attractive enough to draw the necessary number of recruits. Underground miners are to be exempt from call-up to the Forces for the next five years, and the National Union of Mineworkers has agreed to the employment of Poles in the mines. High priority is to be given to all measures which can contribute to increased coal production, such as the production and import of mechanized mining equipment and plant for opencast coal production. The Government will take all possible measures to secure economy in the use of coal and give high priority to the conversion of engines and plant to oil burning. Drastic measures are to be taken to reduce non-industrial consumption of coal, gas and electricity, but the main emphasis in the coal budget is on increased output per man.

In regard to power, while the immediate crisis arises from lack of coal, even at full capacity the power stations of Great Britain cannot meet the demand, and although high priority is given to the production of new generating plant, some years will be required to make up the arrears. The steel shortage results from lack of imports and shortage of coal, but no serious gap is anticipated in 1947 between the supplies available and the essential needs of the major steel-consuming industries, provided that exports are cut to a minimum. Much re-equipment and maintenance work, however, is urgently demanded on the railways, and restoration of shipping is a major task. The Government's agricultural policy is to switch production from crops for direct human consumption to live-stock and live-stock products, especially pigs and poultry, but the world cereal shortage has delayed this policy. More agricultural workers are required; in the building industry, raw materials are the major obstacle to the building programme. There is just a hint that the output per man-year in this industry is far below the level which should be attained.

Reviewing these.industries, the Statement indicates that for 1947 the Government is aiming at a distribution of work between capital equipment and maintenance of 48 per cent for new construction and 52 per cent for plant. The former includes 20 per cent for housing, 6 per cent for new industrial building-a figure which appears to be dangerously low, in view of its bearing on industrial efficiencyand 22 per cent for other building and maintenance, including war damage repairs. The latter is made up of 9 per cent for electricity, gas and Post Office; 4 per cent for roads, bridges, docks, harbours, canals, etc.; 15 per cent for railways, commercial road vehicles, shipping and civil aviation; and 24 per cent for plant for industry, mining and agriculture.

On defence, the White Paper provides for a reduction in the Armed Forces from the December 1946 level of $1,427,000$ to $1,087,000$ by the end of March 1948 , and a fall in the number of workers supplying them. The housing programme is 240,000 new permanent houses and 60,000 temporary houses, and the amount of other capital equipment and maintenance work is to exceed that of a normal pre-war year by at least 15 per cent. Programmes for education, public health and national insurance are to go forward, and a proper degree of efficiency of the public services is to be maintained, with special reference to economy in man-power.

The key to success in reaching these objectives is man-power, and both a larger labour force and a higher output per man-hour are required. Moreover, the present geographical and industrial distribution of the labour force is unsatisfactory. Foreign labour is the only substantial means of increasing our prosspective labour force of 18,300,000 men and women at December 1947, and while the Statement points out that the old arguments against foreign labour are no longer valid, it does not show a proper appreciation of the urgency of the situation to suggest that they are especially required for the under-manned industries : it is surely only there that such labour should be at present recruited if there is any meaning in the Government's plan. The Statement indicates that the Government contemplates an additional 100,000 workers from all sources, and sets forth the desirable distribution of the total $18,400,000$ workers if its objectives are to be realized. "The size and distribution of the labour force are important, but what ultimately counts is the output which the nation produces. We shall not attain the objectives described without an increase in output per man a year. . . . In the longer view, increased output per man-year is the only way to expand production and the standard of living. ... Increased efficiency in the supply of services is just as important as increased output per man-year in the production of goods. . . Action which serves to reduce output per man-year in any industry is directly endangering the attainment of these objectives. The nation cannot afford shorter hours of work unless these can be shown to increase output per man-year. Greater leisure is a very desirable thing, but it is not at the moment a prime essential like imported food. It is not as important as coal or clothing or housing."

That is putting it bluntly, and much of it needs to be said at the present time. But it is disconcerting to read also that the Government only now proposes to invite the representative organisations of industry to co-operate with it in an attempt to establish the facts regarding output; or that it "attaches great importance to the introduction of systems of payment and other arrangements which provide the maximum incentive to increase output". For it is on Government action that the claim which the transport, distribution and other services make upon man-power largely depends. 
Welcome emphasis is laid on research and development in the White Paper, which in referring to a start on longer-range planning for defence research and development with the constitution of the Defence Research Policy Committee, lays stress on the importance of encouraging scientific research and development at a time when economic considerations must severely limit expenditure on new equipment. Although there is evidence that, with the appointment of Sir Henry Tizard as chairman of the Advisory Council on Scientific Policy, knowledge of developments over the whole field of science will be pooled, to the benefit both of the civilian community and of national defence, there is not the same evidence of close co-operation elsewhere.

The references to the Defence Research Policy Committee are, however, encouraging. Through its close link with the Chiefs of Staff, the Committee will be continuously aware of the latest concepts of strategy and operational thought and will itself be able to influence those concepts by reason of its knowledge of future trends in the field of defence science. The Committee will also study programmes for research and development formulated by the Service and Supply Departments in connexion with the preparation of annual estimates, and it will also have brought before it all problems which arise on the higher organisation of defence research and development, and on the requirements of the Service and Supply Departments for scientific man-power, and also major projects for new establishments.

Such organisation providing for effective coordination of effort is the right instrument and condition for securing whole-hearted co-operation. It is essential that a like effort should be made in other fields. Co-operation, as Sir George Schuster has pointed out, is a two-way effort, demanding a lead from the Government as well as response from industry and from the nation. It requires organisation and much more than passive acquiescence in regulations or sporadic demands of the Government from individual interests. Whether or not industrial and trade associations become, as Sir George Schuster suggests, bodies to whom a general strategic task can be entrusted with confidence, to be worked out in close collaboration with the trade unions, no such instrument can be substituted for resolute leadership by the Government.

\section{DEFECTIVE COLOUR VISION IN INDUSTRY}

A COMMITTEE of the Colour Group of the Physical Society has performed a valuable task for the benefit of the community in preparing its recent "Report on Defective Colour Vision in Industry"*. It is written in a style which will be readily understandable by non-technical readers. Starting with a clear account of the nature and incidence of defective colour vision, it goes on to describe various colour vision tests, and mentions an almost alarming variety; an interesting chapter deals with colour vision in industry and the Services, from which it appears that there is a strong case for pre-vocational testing and routine examination of the colour vision of school children. A concluding chapter makes a series of

- Report on Defective Colour Vision in Industry. By a Committee of the Colour Group. Pp. 52. (London: Physical Society, 1946.) 38. $6 d$. net. recommendations, of which perhaps the most important is that "all children should be tested at school at the age of 13 or over, using one of the approved Confusion Chart Tests". Confusion chart tests are also suggested as suitable for pre-vocational tests for a great variety of industries and trades.

Defective colour vision is found, we are told, in about 8 per cent of the male population, but only in a much smaller percentage of women. Of the males, only about 2 per cent are 'dichromats', a class which can match all hues with an additive mixture of two suitable primary colours, and also would be liable to make the grossest errors in colour matching; but there are many in the remaining 6 per cent who, while not liable to confuse (say) reds and greens under good lighting conditions, nevertheless have inferior powers of colour discrimination and may make substantial mistakes if the light is poor. In this group are found the 'anomalous trichromats' who, while requiring three suitable primary colours to match all hues by these primaries combined in suitable proportions, nevertheless do not usually agree with such a match made by a normal person. It is important to realize, as. is brought out by the report, that colour-defectiveness exists in many degrees of severity; there is no single condition which can be called 'colour blind'.

While the Services, public transport undertakings, and some industrial organisations prevent the entry of unsuitable persons by adequate tests, there is no consistent public policy in attempting to ensure that colour-defective persons do not become occupational misfits. The report instances the textile trades, drapery, electrical industries, paper-making, and many other cases in which a certain proportion (perhaps 20 per cent in some cases) of the employees must perform operations depending on sensitive colour discrimination. In many cases the matter is left to a kind of natural selection; people who find difficulty avoid such jobs, or they are found to be in difficulties and transferred to alternative posts. The Committee remarks in this connexion : "We have a clear impression that this loss of time and efficiency is by no means small, and that there would be real value, both from employers' and employees' points of view, in ensuring that colour-defective persons did not embark on lines of work where normal colour vision is necessary or highly desirable".

The result of a colour vision test is a matter of prime importance to the individual whose career may depend upon it. While stressing the importance of the elimination of colour-defectives from certain callings, the report proposes that the tests should occur before the individual has developed hopes which must be disappointed. We might add that any person failing should be convinced that justice has been done. While this last point is not neglected in the report, it does not seem to have been given enough weight.

The recommendation for the testing of school children is excellent, and there is no doubt that it should be implemented as soon as possible. There will be some boys who will have already been attracted to the Navy or merchant marine, and will, if colourdefective, have to turn their ambitions elsewhere. The defect is just as important in such a case as an error of refraction, and even if the test occupies five minutes of the time of a trained person, is that really an important objection? It is possible that the teachers, who already nobly carry a great burden of duties besides their normal teaching, might be able to 